\title{
When Dark Triad Personality leads to Supervisors Expediency: An Islamic work Perspective
}

\author{
Hina Fayyaz ${ }^{1 *}$, Amir Gulzar ${ }^{2}$, Nida Abbass ${ }^{3}$ \\ 1,2,3 Department of Business Administration, Foundation University, Islamabad, Pakistan
}

\section{Keywords}

Religiosity

Dark Triad

Supervisor Expediency

Islamic Work Ethics

Received: 04 July 2019

Accepted: 16 March 2020

\begin{abstract}
The aim of this paper is to examine the relationship between dark triad personality and supervisor expediency. The researchers further investigated if Islamic Work Ethics (IWE) moderates the positive association between dark triad and supervisor expediency; such that the relationship is weaker when IWE is high. Theoretical framework developed in present study is based on two theories i.e., trait theory and theory of planned behavior. The two set data was collected from employees working in health sector of Pakistan. Set one questionnaires were filled by employees on supervisory positions, they rated their own personality traits and belief in Islamic work ethics. Set two questionnaires were filled by the immediate subordinates of supervisors who filled set one. They were asked to rate supervisor's expediency. Data was collected from 241 supervisors and 241 respective subordinates. Code was assigned to keep the track of supervisors and their respective subordinates. Confidentiality was ensured to avoid any bias. The research result revealed that Machiavellianism, narcissism and psychopathy positively and significantly impacts supervisor expediency. IWE moderates the positive association between Machiavellianism, narcissism and supervisor expediency. However, the moderation result was found insignificant in the case of Psychopathy and supervisor expediency. Empirical evidences confirmed that dark triad of personality leads to supervisor expediency. The theoretical model tested in the study provides insight and empirical evidences in literature. Implications for the managers and future research directions are also discussed.
\end{abstract}

KAUJIE Classification: P0

JEL Classification: M10 


\section{INTRODUCTION}

In recent years scholars and practitioners have given a great deal of attention to destructive leadership because of its detrimental effects on the organization (Krasikova, Green, \& LeBreton, 2013). Destructive leadership (DL) is a wide construct referring to many deleterious behaviors of leaders as for example abusive supervision, supervisor undermining the subordinates, petty tyrants and despotic leadership (Ashforth, 1994; De Hoogh \& Den Hartog, 2008; Duffy, Ganster, \& Pagon, 2002; Tepper, 2000). DL is defined as supervisor, leader or manager behavior that disrupts the legitimate interests of organization by undermining organizational goals, resources, tasks, and effectiveness (Einarsen, Aasland, \& Skogstad, 2007). In recent times, Greenbaum, Mawritz, Bonner, Webster and Kim (2018) identified another such leadership behavior and labelled it Supervisor Expediency (SE). They defined SE as supervisor's involvement in immoral practices to accelerate work for self-centered purpose in an organization.

Enron, Tyco International, WorldCom, Adelphia and Transmile are examples of corporate leadership failure, leaders' involvement in unethical behavior and its harmful effects. The scandal expose how Enron CEO Andrew Fastow, while hiding small amount of debt lead to the much worse outcomes (Welsh, Ordonez, Snyder, \& Christian, 2015). Researchers for last 30 years are trying to define why individual at workplace make unscrupulous choices. The current research is a response to recent call by Greenbaum, Mawritz, Bonner, Webster, and Kim (2018) who suggested conducting research for validating and identifying outcomes and antecedents of supervisor expediency. As supervisor expediency is a recently conceptualized construct, research on this leadership behavior is scarce. The existent study is an endeavor to develop and test a framework on antecedents of SE; and for this dark triad personality traits are highlighted as probable antecedent of SE.

Conceptual framework of current study is based on Trait Theory (Allport, 1937). He defined traits as characteristics of personality that influence behavior. Moreover, this theory postulates that individuals' characteristics and qualities standardize behavior. Furthermore, Allport (1961) elaborated "Personality is the dynamic organization within the individual of those psychophysical systems that determine his characteristics, behavior and thought" (p. 28). This purports that individual possess combination of different personality traits that determine their behavior. Personality have negative traits as well, that are labelled as dark triad by (Paulhus \& Williams, 2002). Dark Triad (DT) is an important contribution in Personality Psychology. Three facets of DT are (i) Machiavellianism; (ii) Narcissism; and, (iii) Psychopathy. It is argued that these facets are the antecedents of supervisor expediency (SE), which is a form of unethical supervision where supervisor bend rules to complete tasks and modify performance numbers.

In addition, this research pinpoints IWE as a potential moderator between facets of DT and SE. IWE is considered as probable moderator because it has its focus on inhibition from unethical behavior, while its essentials include hard work, commitment and dedication (Khan, Abbass, Gul, \& Raja, 2015). Yousef (2000) stated that IWE emphasize on intentions. Moderator discussion is grounded on theory of planned behavior (Ajzen, 1985) that states that beliefs and intentions affect individuals' behavior and discusses individual's ability of 
self- control. In the extant research it is argued that even in the presence of dark triads the individual having belief in Allah and IWE will refrain him/herself from getting involved in expediency.

Greenbaum (2009) argued that ethical leadership literature needs to take into consideration the impacts of unethical leadership. Moreover, research on unethical leadership practices is of critical importance. In present research, unethical leadership practices particularly refer to supervisor expediency. Greenbaum et al. (2018) discussed that supervisor expediency can be a critical issue for an organization.

The threefold contributions of present study includes (i) to the best of researchers' knowledge the impact of DT on supervisor expediency has not been empirically tested yet. Hence, the objective of this research is to fill this theoretical gap; (ii) based on trait theory and theory of planned behavior, researchers provide comprehension about the underlying process associated with dark triad, IWE and supervisor expediency; and, (iii) this research will help the practitioners in organization to understand and give consideration to the factors that can lead to supervisor expediency at workplace.

\section{LITERATURE REVIEW}

Trait theory assumes that personality traits shape individual's behavior (Allport, 1937; 1961) According to trait theorists individuals hold certain personality traits that regulate their behavior. Personality traits are the enduring characteristics that define behavior (Robbins \& Judge, 2017). Like other personality traits, dark triads of personality motivates to strive for personal objectives (Forsyth, Bank, \& McDaniel, 2012). Detailed discussion is provided below why dark triads can positively and significantly result in supervisor expediency.

\section{Machiavellianism and Supervisor Expediency}

Individuals with Machiavellianism tendencies are manipulative and deceptive to reach desired personal ends, and it does not matter how desired ends are achieved (Christie \& Geis, 1970). Machiavellians are more focused on personal gains likewise; a supervisor expedient in his behavior is only concerned with self-regard. Researchers for instance Dahling, Whitaker, and Levy (2009) specified that individuals with Machiavellianism tendencies consider themselves as skillful manipulators. This manipulation skill allows individuals to establish social networks, gain trust and respect of colleagues and achieve desired outcomes (Forsyth et al., 2012).

Robbins and Judge (2017) indicated that an individual with high Machiavellianism maintains emotional distance and firmly believes that ends justify means, target should be achieved, though it does not matter how it is to be achieved. Furthermore, research has also found that individuals high in Machiavellianism manipulate more. By manipulating others individual with Machiavellianism trait, they try to gain advantage from other to satisfy their own interest (Jonason, Slomski, \& Partyka, 2012). Similarly, a supervisor involved in expediency is also interested to achieve targets to satisfy self-interest. Moreover, meta-analysis by (Kish-Gephart, Harrison, \& Trevino, 2010) underlined Machiavellianism as an antecedent 
of unethical intention or behavior. Trait theorist argue that dominant personality traits of an individual predict their behavior (Allport, 1937). Thus in line with the above literature it is hypothesized that:

H1: Machiavellianism is positively and significantly related to supervisor expediency.

\section{Psychopaths and Supervisor Expediency}

Psychopaths are impulsive, hostile and independent thinkers (LeBreton, Binning, \& Adorno, 2006). Psychopaths are thoughtless and hostile, having tendency to ignore and violate organizational rules (Eysenck, 1967; 2012). Literature suggests that Psychopaths lack guilt when their action cause harm (Forsyth, Banks, \& McDaniel, 2012). Psychopathy might be positively related to advancement in an organization, the reason behind it is that psychopaths use hard influence tactics on others as for example manipulation and threat (Jonason, Slomski, \& Partyka, 2012). Robbins and Judge (2017) indicate that cunningness possessed by psychopaths help them achieve power in organization, while it does not yield healthy results for the organization. In-depth research on psychopathy revealed that individuals with such tendencies are successful in business because of two main reasons i.e., (i) their consistent focus is on target achievement even if it is on the cost of others; and, (ii) they also possess charismatic social skills (DePaulo, 2010; Yang \& Raine, 2008). An extensive analysis by Babiak and Hare (2006) with the title of "snakes in suits" highlighted that $3.5 \%$ of top officials grossed high score on the measure of psychopathy. Supervisor expediency is basically leaders' involvement in morally questionable behavior in order to expedite his work (Greenbaum, 2007).

The Webster's New World College Dictionary defines expediency as "the doing or consideration of what is of selfish use or advantage rather than of what is right or just self-interest" (p. 500). Greenbaum et al. (2018) elaborate that SE is use of immoral practices by supervisors to speed up their work for self-serving purpose. These supervisors behave unethically for three main reasons i.e., (i) self-interest is major concern; (ii) going against approved organizational rules; and, (iii) disrupting commonly believed moral norms of behavior. Thus in line with the above literature, researchers in present study hypothesize:

H2: Psychopathy is positively and significantly related to supervisor expediency.

\section{Narcissists and Supervisor Expediency}

Narcissists are anxious, egoistic, self-centered and self-obsessed that disrupt their moral believes (Djeriouat \& Tremoliere, 2014). A person who is considered to be narcissist believes in self-importance and he/she wants excessive appreciation. Research proves that managers and leaders scoring high in Narcissism believe that self-centeredness is required to succeed. High level of motivation is also reported by Narcissist. Andreassen, Ursin, Eriksen, and Pallesen (2012) conducted study on Norwegian bank employees, which revealed that an individual scoring high on Narcissism enjoys work. Narcissism is found to be positively related to destructive work outcomes and counterproductive work behavior (Robbins \& Judge, 2017). Morf and Rhodewalt (2001) state that Narcissism includes over stated view of self, desire to achieve success and admiration. Literature suggests that Narcissists are engaged 
in organizational politicking and impression management (Vohs, Baumeister, \& Ciarocco, 2005; Vredenburgh \& Shea-VanFossen, 2009).

Narcissist individuals may get involved in workplace bullying, incivility, white-collar crime and aggression (Bogart, Benotsch, \& Pavlovic, 2004). Greenbaum and Folger (2008) assert that supervisor expediency is morally questionable, and it occurs when supervisors are engaged in ethically questionable behavior to accelerate their work for self-interest. On the basis of above arguments it is hypothesized:

H3: Narcissism positively and significantly affects emergence of supervisor expediency.

\section{Moderating Role of IWE}

Ali (1992) indicated IWE is an orientation towards work. Work is a virtue to establish a balance between individual and social life. The last Prophet Hazrat Muhammad (PBUH) indicated that on the day of judgment the honest Muslim business man will stand with martyrs. IWE refer to a philosophy prescribed in Qur'ān and Sunnah of the Prophet (Peace Be Upon Him). A Muslim believer will hold up to this notion while working (Beekun \& Badawi, 2005). Previous researches prove that IWE or the degree to which an individual observes Islamic work values in his job, confers employee with affirmative vitality, drives to undertake assiduous work effort and gest involved in such conduct that is considered to be morally right (Ali, 2005; Murtaza et al., 2016). IWE imply focusing on commitment to work and avoiding wealth accrual through immoral means (Khan et al., 2015). Yousef (2001) indicated that IWE gave more importance to intentions than results. Any action that is intended to cause harm to anyone, but benefiting to those undertaking it, is considered illegitimate in Islam (Ali \& Al-Owaihan, 2008). Researchers affirm that ethics are moral ideologies that assist the individuals to distinguish between the right and the wrong (Khan et al., 2015). Syed and Ali (2010) emphasized that Muslims are required to follow Islamic code of morals and surrender to Allah and His will. Conferring to Islamic philosophies, Rice (1999) stated "it is the ethic that dominates economics and not the other way around" (p. 346). It is written in Qur'ān that "for all people, there are ranks according to their deeds" (Qur'ān 6:132).

Theory of planned behavior illustrates that individuals' beliefs, attitude and intention lead to behavior, while individuals have ability to control behavior (Fishbein \& Ajzen 1975, Fishbein \& Ajzen, 1980). Relying on this theory, researcher argues that a person who believes in the philosophy of IWE will refrain from involving in unethical practices even in the presence of dark triads because of self-control. Thus researchers hypothesize that:

H4: IWE moderate the positive relationship between Machiavellianism and supervisor expediency such that the relationship is weaker when IWE are high.

H5: IWE moderate the positive relationship between the Psychopathy and supervisor expediency such that the relationship is weaker when IWE are high.

H6: IWE moderate the positive relationship between the Narcissism and supervisor expediency such that the relationship is weaker when IWE are high. 


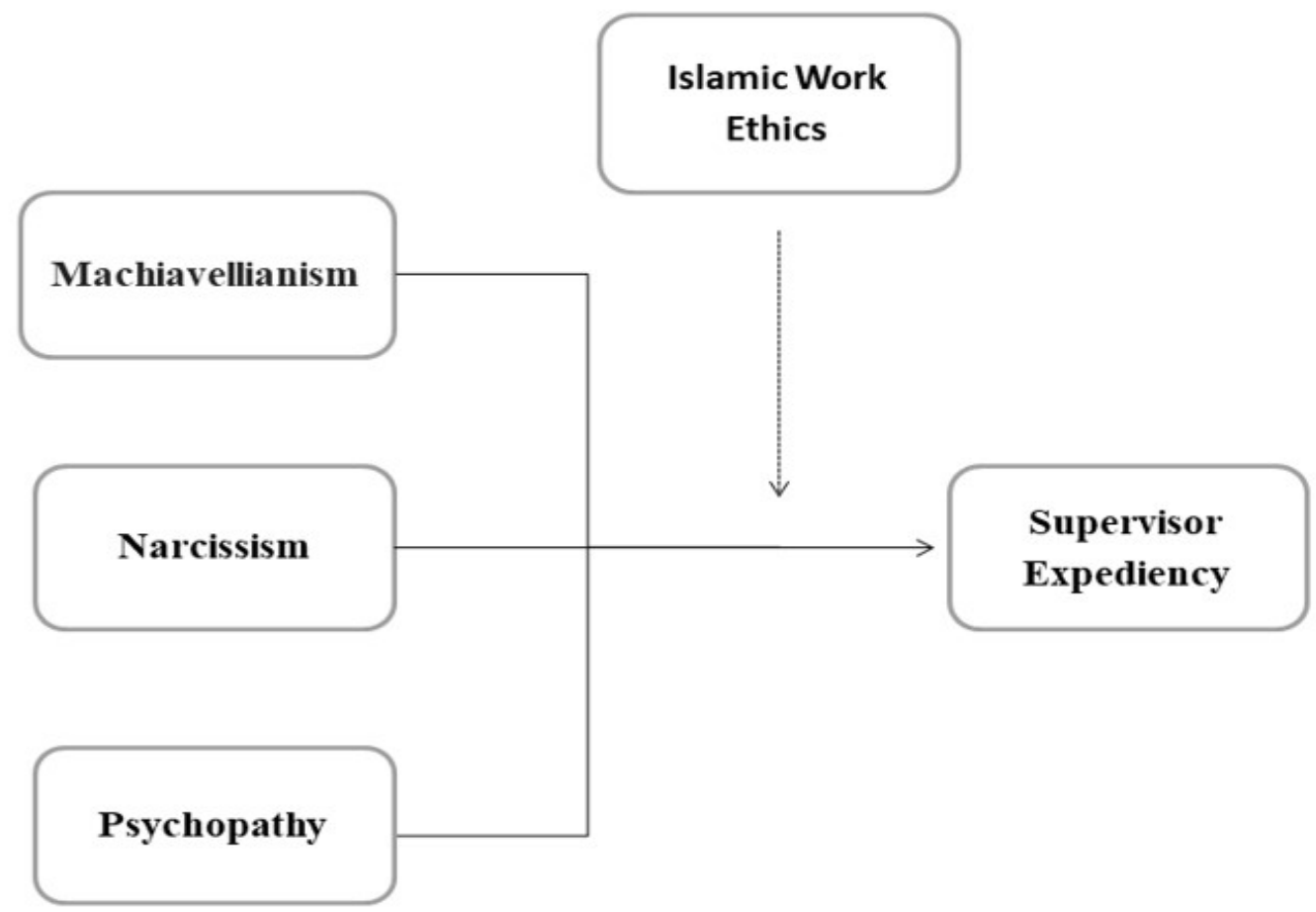

FIGURE 1. Theoretical framework

\section{METHODOLOGY}

\section{Participants and Procedure}

In the extant research, data were collected from medical professionals working in nine different hospitals in Pakistan. Medical professionals included employees working in medical sector who were dealing with the patients on daily basis. Some of the employees working in health sector were general practitioners, surgeons, medical physician, radiologists, and nurses. In Pakistan medical professional are facing some severe problems in service delivery (PHSP, 2018). Further, the health sector in Pakistan consists of less number of medical professional i.e. doctors and nurses (Ali \& Wajidi, 2013). Hence, in order to ensure that this sector works smoothly, it seemed imperative to explore the current model in this sector.

In phase one of the study the administration staff in each of the hospital was contacted and a written application was put forward. The study was initiated after acceptance of the written application and approval by the competent authority. The willing participants who were holding managerial positions in health sector were selected on the basis of convenience sampling. The study participants were given a questionnaire using a prepaid envelope. They were asked to give their response regarding their personality traits and IWE. In order to ensure the element of confidentiality the participants were asked to return the questionnaire in sealed prepaid envelope directly to the researcher. To keep a track of every participant code was assigned to each questionnaire.

In the second phase, the researcher contacted the subordinate of those employees who filled the first set of questionnaire. The subordinates were given a coded questionnaire using 
a prepaid envelope. The subordinates were requested to evaluate their respective managers in terms of their supervisor expediency. The subordinates returned the questionnaire to the researcher on the mentioned addressed using prepaid envelopes. Each questionnaire was filled by supervisor and his subordinate. Initially, 300 questionnaires were distributed and at the end of the data collection phase, 241 completely filled were received. The response rate for the study was $69 \%$. Each questionnaire was filled by supervisor and his respective subordinate. Thus, the sample of the study consisted of 241 supervisors and 241 subordinates.

\section{Measures Dark Triad}

The present study assessed DT with scale developed by Jones and Paulhus (2014). Three personality traits i.e., Machiavellianism, Narcissism and Psychopathy were rated. Each trait had nine questions that were rated on 5 point likert scale ranging from 1= Strongly Disagree to $5=$ Strongly Agree. Some of the sample items are, "I like to use clever manipulation to get my way", "People see me as a natural leader" and "I like to get revenge on authorities". The internal reliability of the scale was: Machiavellianism (.79), Narcissism (.81) and Psychopathy (.84).

IWE

IWE was assessed with 17-item scale developed by Ali (1992). The scale items were rated on 5-point likert scale, ranging from $1=$ strongly disagree to $5=$ strongly agree. Items of scale included "Dedication to work is virtue" and "One should carry work out to the best of one's ability". Employees on managerial or supervisory position rated this scale. The cronbach alpha of the scale was (.78).

\section{Supervisor Expediency}

Four items scale by Greenbaum et al. (2018) was used to assess expediency in the current study. Focal employees rated their supervisor on 5-point likert scale ranging from $1=$ strongly disagree to $5=$ strongly agree. Sample items are "Cuts corners to complete work assignments more quickly" and "Alters performance numbers to appear more successful". The cronbach alpha of the scale was .93 .

\section{Data Analysis Analytical Strategy}

The analysis of the extant research was conducted into three phases. In the initial phase confirmatory factor analysis (CFA) was conducted to evaluate the validity of the instrument used. To establish the model fitness of the CFA model, numerous parameter were considered such as the values of $\chi^{2}$ test statistic along with degrees of freedom, the value of root mean square error of approximation and comparative fit index (Hu \& Bentler, 1999). To ensure that the data had no issues related to common method variance, Harman single factor test was also conducted. In the last phase of the data analysis hierarchical regression was conducted to test the proposed hypotheses.

\section{RESULTS}

\section{Confirmatory Factor Analysis (CFA)}

In order to established the model fitness five models were compared. Model 1 comprised one 
factors inculcating all the items of Machiavellianism, Narcissism, Psychopathy, IWE and supervisor expediency. Model two consisted of two factors where one factor consisted of all the items of Machiavellianism, Narcissism, and Psychopathy, while factor two contained all the items of IWE and supervisor expediency. Model 3 comprised three items where first factor contained all the items of Machiavellianism, Narcissism, and Psychopathy, second factor consisted of all the items of IWE, while the last factor consisted of all the factors of supervisor expediency. Model 4 comprised four factors where first factor contained all the items of Machiavellianism, and Narcissism, second factor composed of all the items of Psychopathy, third factor consisted of all the items of supervisor expediency, while the last factor contained all the items of IWE. The final model i.e. model 5 consisted of five factor where all the factors were loaded on their respective factor. Once the items with low factor loading were removed and few items were covaried, the model fitness was achieved. As suggested by Hu and Bentler (1999) the final model was in acceptable range, the statistics achieved show $\chi^{2} / d f=1.9, \mathrm{CFI}=0.93$; RMSEA $=0.80$. Table 1 depicts model fitness for each model and its comparison with five factor model.

TABLE 1

Summary of CFA Results

\begin{tabular}{|c|c|c|c|c|}
\hline Model & $X^{2}(\mathrm{df}), p$ & CFI & RMSEA & $\begin{array}{l}\text { Comparison with } \\
\text { five-factor model } \\
\left(\Delta X^{2}(\mathrm{df}), p\right)\end{array}$ \\
\hline Model 1 (One Factor) & $6802.04(1308), p<.01$ & .62 & .19 & $540.77, \mathrm{p}<.01$ \\
\hline Model 2 (Two Factor) & $6261.27(1316), p<.01$ & .56 & .17 & $572.36, \mathrm{p}<.01$ \\
\hline Model 3 (Three Factor) & $5688.91(1297), p<.01$ & .67 & .14 & $1998.76, \mathrm{p}<.01$ \\
\hline Model 4 (Four Factor) & $3690.15(1287), p<.01$ & .73 & .11 & $1650.81, \mathrm{p}<.01$ \\
\hline Model 5 (Five Factor) & $2039.34(1067), p<.01$ & .93 & .08 & \\
\hline
\end{tabular}

TABLE 2 Convergent and Divergent Validities

\begin{tabular}{lccc}
\hline \hline Variables & CR & AVE & MSV \\
\hline 1. Machiavellianism & .79 & .62 & .42 \\
2. Narcissism & .81 & .66 & .46 \\
3. Psychopathy & .84 & .72 & .43 \\
4. Islamic work ethics & .78 & .67 & .42 \\
5. Supervisor expediency & .93 & .77 & .40 \\
\hline \hline
\end{tabular}

\section{Convergent and Divergent validities}

In the next phase of the data analysis, validities that includes convergent and discriminant were accessed by extracting the mean shared variance and average variance. The table 2 depicts that the average variance obtained was greater than the mean shared variance verifying the discriminant validity of the variables under study. 
Similarly, the AVE was higher than 0.5 and the composite reliability for all the constructs was higher than 0.7 establishing the convergent validity of the variables.

TABLE 3

Means, Standard Deviations and Correlations af all the Constructs Under Study

\begin{tabular}{lccccccccccc}
\hline \hline & Mean & S.D & 1 & 2 & 3 & 4 & 5 & 6 & 7 & 8 & 9 \\
\hline 1 Gender & 1.59 & 0.49 & 1 & & & & & & & & \\
2 Age & 1.7 & 0.75 & 0.1 & 1 & & & & & & \\
3 Education & 1.66 & 0.67 & 0.04 & -0.11 & 1 & & & & & \\
4 Tenure & 2.33 & 0.84 & -0.01 & 0.06 & $.40^{* *}$ & 1 & & & & \\
5 Machiavellianism & 3.46 & 0.46 & 0.02 & $-.16^{*}$ & $.30^{* *}$ & $.16^{*}$ & 1 & & & \\
6 Narcissists & 2.97 & 0.46 & 0.08 & 0.05 & $.15^{*}$ & 0.11 & 0.13 & 1 & & \\
7 Psychopaths & 3.01 & 0.54 & -0.01 & 0.1 & $.16^{*}$ & 0.12 & 0.04 & $.45^{* *}$ & 1 & & \\
8 Supervisor Expediency & 2.73 & 0.8 & 0.07 & -0.02 & 0.12 & 0.12 & $.22^{* *}$ & $.36^{* *}$ & $.43^{* *}$ & 1 & \\
9 Islamic Work Ethics & 3.11 & 0.98 & -0.02 & 0.06 & 0.01 & $-.15^{*}$ & $-.39^{* *}$ & $-.22^{* *}$ & $-.17^{*}$ & $-.34^{* *}$ & 1 \\
\hline \hline
\end{tabular}

TABLE 4

Results of Hierarchical Regression Analyses

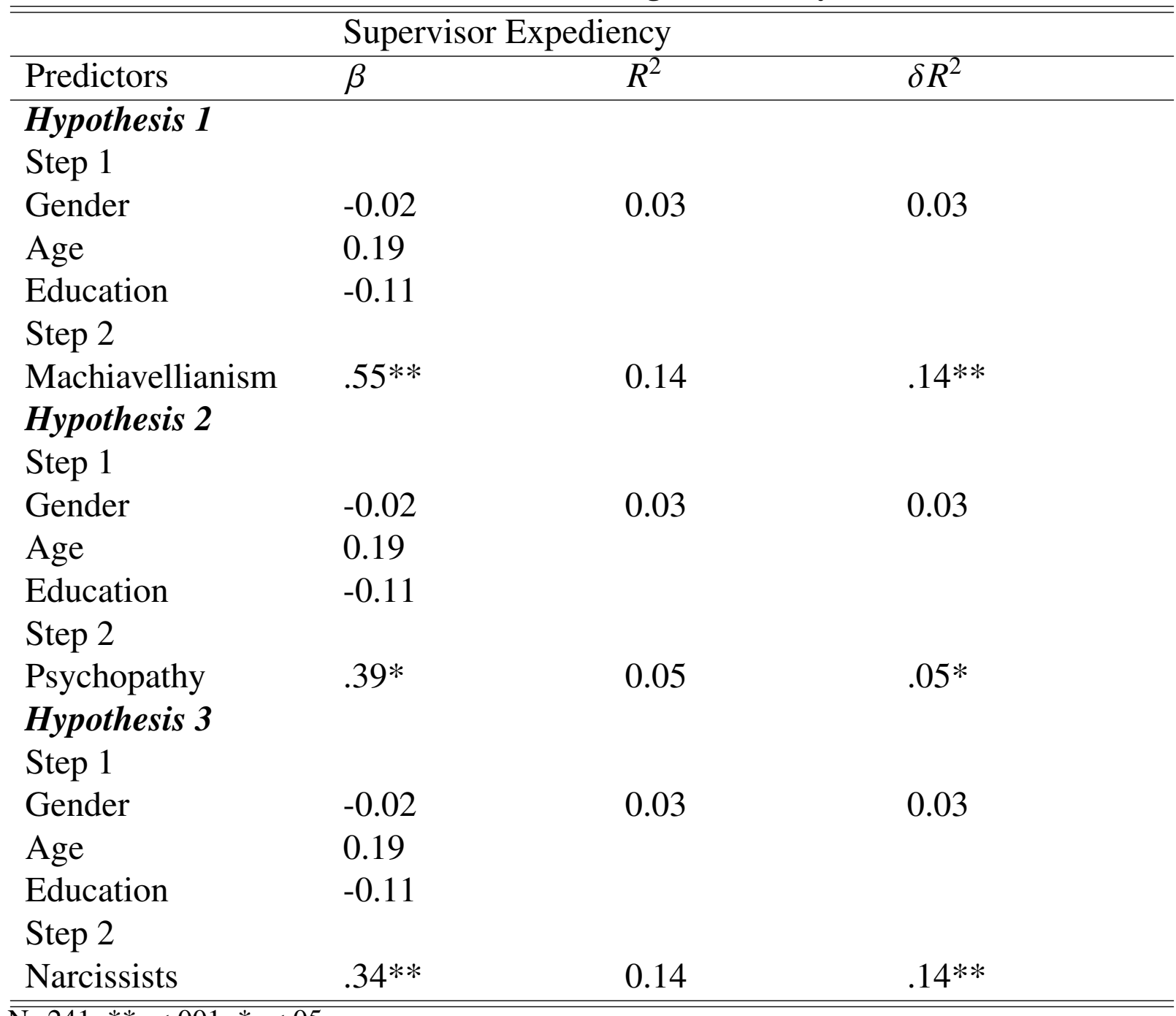

$\mathrm{N}=241 ; * * p<.001 ; * p<.05$ 
TABLE 5

Demonstrates Hierarchical Regression Analyses for Moderation

\begin{tabular}{|c|c|c|c|}
\hline \multicolumn{4}{|c|}{ Supervisor Expediency } \\
\hline Predictors & $\beta$ & $R^{2}$ & $\delta R^{2}$ \\
\hline \multicolumn{4}{|c|}{ Moderation Hypothesis 4} \\
\hline \multicolumn{4}{|c|}{ Step 1} \\
\hline Gender & -0.02 & & \\
\hline Age & 0.19 & 0.03 & 0.03 \\
\hline Education & -0.11 & & \\
\hline \multicolumn{4}{|l|}{ Step 2} \\
\hline Machiavellianism & $.45^{* *}$ & & \\
\hline Islamic Work Ethics & $-.33 * *$ & .12 & $.12 * *$ \\
\hline \multicolumn{4}{|l|}{ Step 3} \\
\hline Mach x IWE & $-.23 * *$ & .15 & $.02 * *$ \\
\hline \multicolumn{4}{|c|}{ Moderation Hypothesis } \\
\hline \multicolumn{4}{|c|}{5} \\
\hline \multicolumn{4}{|l|}{ Step 1} \\
\hline Gender & -.02 & & \\
\hline Age & .19 & .030 & .030 \\
\hline Education & -.11 & & \\
\hline \multicolumn{4}{|l|}{ Step 2} \\
\hline Psychopathy & $.09 *$ & & \\
\hline Islamic Work Ethics & $-.27 *$ & .21 & $.21 *$ \\
\hline \multicolumn{4}{|l|}{ Step 3} \\
\hline Psy x IWE & -.19 & .23 & .02 \\
\hline \multicolumn{4}{|c|}{ Moderation Hypothesis } \\
\hline \multicolumn{4}{|c|}{6 Step 1} \\
\hline Gender & -.02 & & \\
\hline Age & .19 & .030 & .030 \\
\hline Education & -.11 & & \\
\hline \multicolumn{4}{|l|}{ Step 2} \\
\hline Narcissists & $.21 * *$ & & \\
\hline Islamic Work Ethics & $-.59 * *$ & .22 & $.22 * *$ \\
\hline \multicolumn{4}{|l|}{ Step 2} \\
\hline Nar x IWE & $-.23 * *$ & .24 & $.02 * *$ \\
\hline
\end{tabular}

Harman single-factor test was conducted to ensure that the data had no issues related to common method variance. The initial factor showed 44 percent of the total variance that falls in the suitable boundary (Podsakoff, MacKenzie, Lee, \& Podsakoff, 2003).

The Table 3 depicts that the correlation achieved was in proposed direction. The correlation among variables shows provisional support for hypothesis. 
All the hypotheses were tested using step-wise regression. With reference to table 4 findings of the current study suggest that Hypotheses 1, 2 and 3 have been accepted. These hypotheses underlined about the direct relationship between dark triads (Machiavellianism, Narcissism, Psychopathy) and supervisor expediency.

Table 5 depicts the results of step-wise regression analysis, in order to test hypothesis 4, 5 and 6. These hypotheses emphasize on the moderation effect of IWE, between the relationship of DT i.e., Machiavellianism, Narcissism, and Psychopathy and supervisor expediency. Before composing the interaction term to test the moderation hypotheses, the independent variables along with the moderator were centered (Aiken, West, \& Reno, 1991). For each moderation hypothesis, demographics were entered in the first step, independent variable was entered in the second and in the last phase of the analysis the interaction term was added.

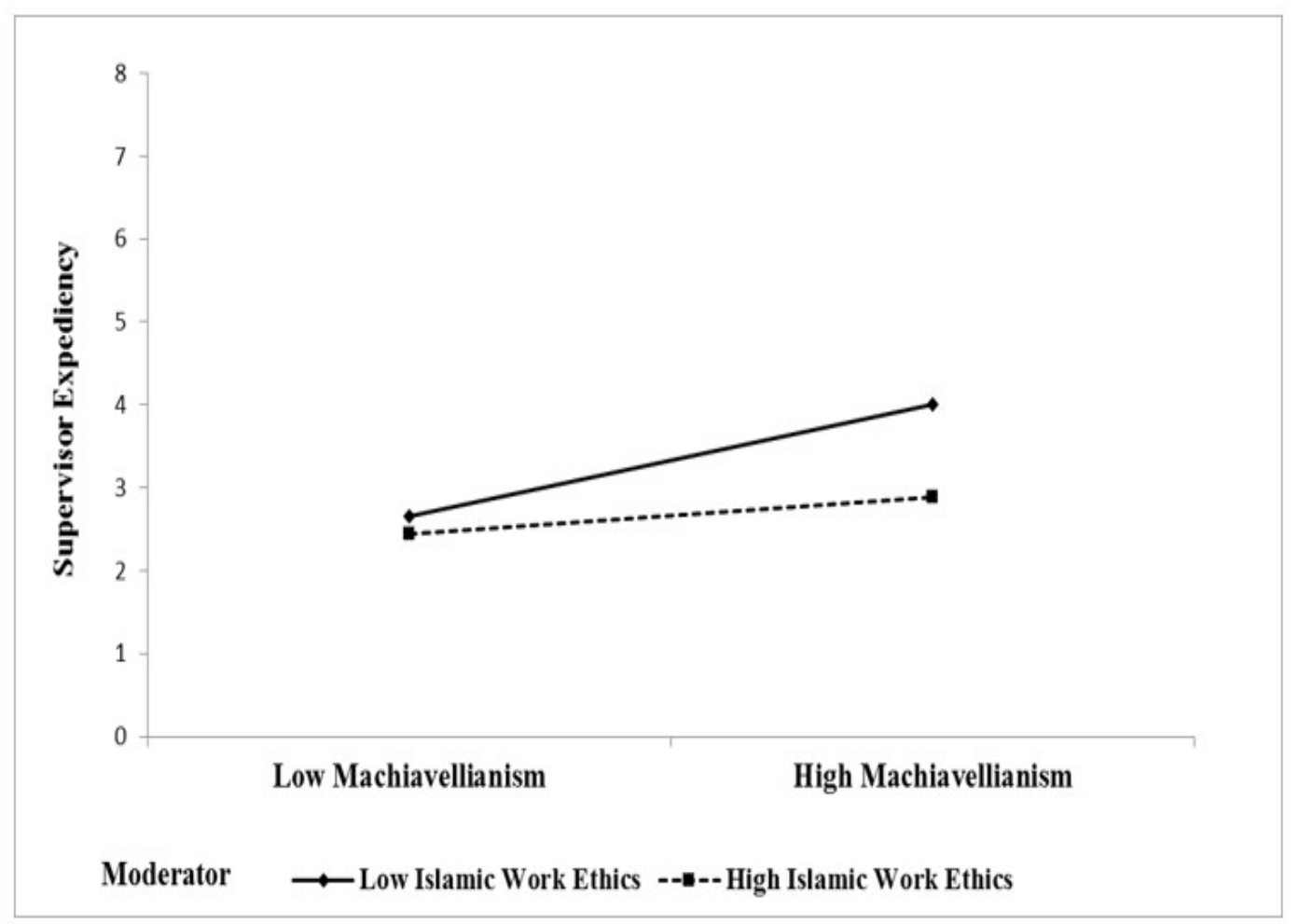

FIGURE 2. Moderation effect of IWE between Machiavellianism and SE

For hypothesis 4 interaction term was found to be significant establishing that IWE moderates the relationship between Machiavellianism and SE such that this positive relationship weakens when IWE is high. Figure 2 demonstrate the relationship between Machiavellianism and SE at high and low level of IWE. The approach opted for analyzing the interaction effect of Machiavellianism and Islamic work ethics on supervisor Expediency is proposed by Dawson (2014). The slope depicts that the positive relationship between Machiavellianism and Supervisor Expediency is diluted when the degree of Islamic work ethics is high. Hence, hypothesis 6 has been accepted.

For hypothesis 5 interaction term was found to be insignificant indicating that IWE does not work as a moderator between Psychopathy and Supervisor Expediency. Hence, hypothesis 5 has been rejected. For hypothesis 6 , the interaction term was found to be significant 
affirming that IWE moderates the relationship between narcissists and Supervisor Expediency such that this positive relationship mitigated when IWE is high. Figure 3 shows the graph that was made using the two way interaction approach proposed by Dawson (2014). It shows the relationship between Narcissists and Supervisor Expediency at high and low levels of IWE. The slope depicts that the positive relationship between Narcissists and Supervisor Expediency is weakened when the degree of Islamic work Ethics is high. Hence, hypothesis 4 has been accepted.

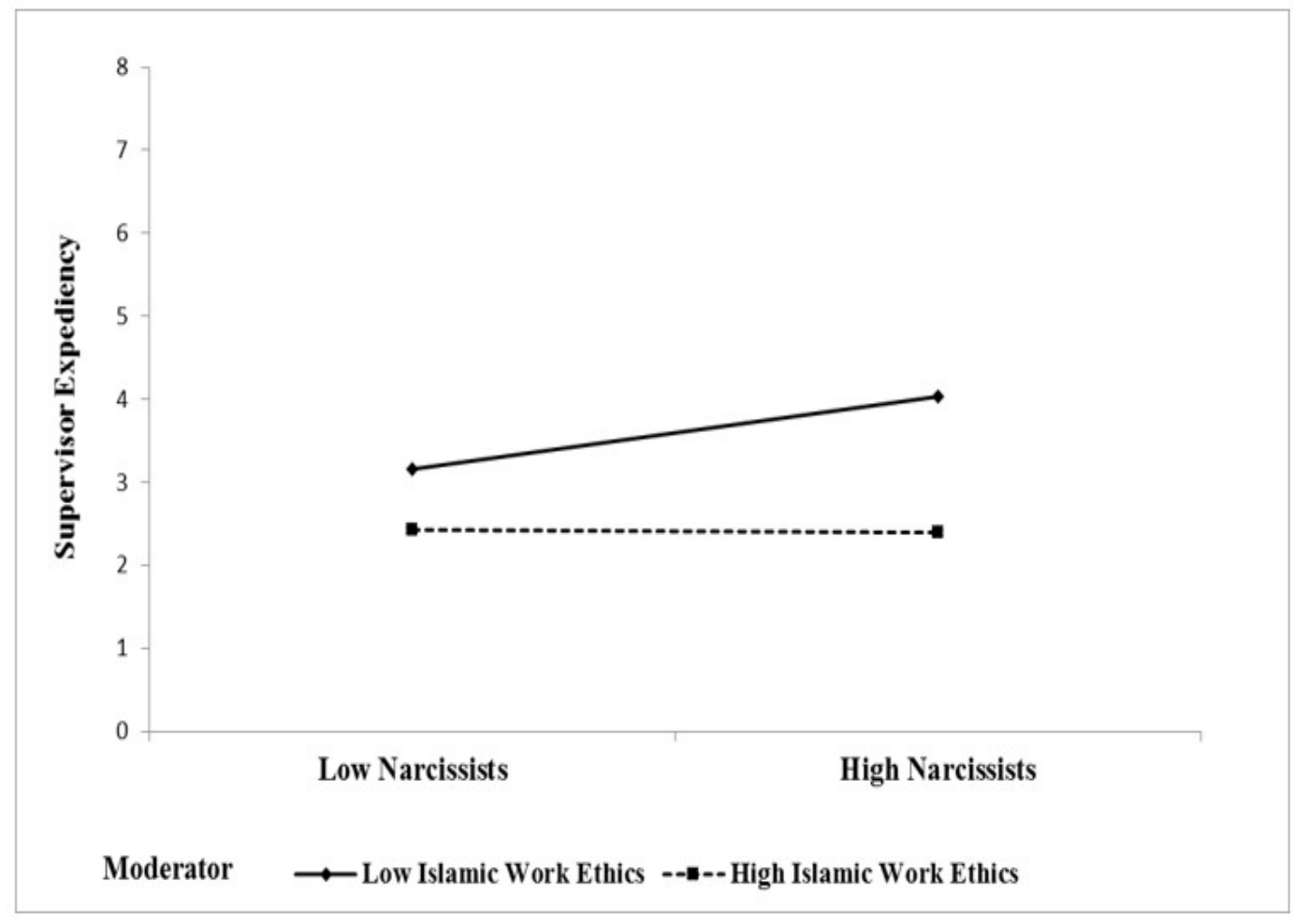

FIGURE 3. Moderation effect of IWE between Narcissism and SE

Figure 2 and Figure 3 illustrate that IWE moderate the positive relationship between Machiavellianism, Narcissism and supervisor expediency such that when IWE are high this relationship is weak. The slope depicts that the positive association between Machiavellianism, Narcissism and SE is diluted when the degree of IWE is high.

\section{Discussion}

This study explored the relationship between dark triad and supervisor expediency. Moreover, IWE as a potential moderator has been identified between the positive relationship of dark triad and supervisor expediency, such that individuals believing in the philosophy of IWE will less likely to be engaged in supervisor expediency. Researcher hypothesized that dark triad positively and significantly affected the emergence of supervisor expediency based on trait theory (Allport, 1937). Further it was hypothesized that IWE moderated the relationship between DT and supervisor expediency such that the relationship is weak when IWE are high based on theory of planned behavior.

The main hypotheses framed in the present study were supported by the results. The 
facets of DT i.e., (i) Machiavellianism; (ii) narcissism; and, (iii) psychopathy positively and significantly affected the supervisor expediency; relying on trait theories it was predicted that individual with dark triad would be more inclined towards supervisor expediency. Palmer, Komarraju, Carter, and Karau (2017) proved that individual with higher level of Machiavellianism, Narcissism and Psychopathy were found to be involved in counterproductive work behavior. In line with this research, current research results confirm that dark triad positively affects emergence of supervisor expedient behavior.

Drawing on theory of planned behavior, IWE was discussed as a moderator. The research results confirm that IWE moderate the relationship between Machiavellianism, Narcissism and supervisor expediency accepting hypothesis 4 and 6 formulated in the study. IWE are the guidelines provided by Qur'ān and Sunnah. It was emphasized that an individual even with the presence of dark triads would refrain him / herself from involving in unethical behavior i.e., expediency. Khan et al.(2015) argued that individuals believing in philosophy of IWE would less likely involve in undesirable behavior. Yousef (2001) stated that adopting IWE would lead to commitment and justice at workplace. Similarly, figure 2 and figure 3 confirm that IWE moderate the positive relationship between Machiavellianism, Narcissism and supervisor expediency such that when IWE are high this relationship is weak. Hypothesis 5 stating that IWE is a potential moderator between Psychopathy and supervisory expediency was rejected as empirical evidence revealed insignificant results. Prior researches identified two main elements related to psychopathy, first is insensitivity and second is lack of self-control (Cleckley, 1976; Hare \& Neumann, 2008; Hare \& Throvaldson, 1970). Lack of self-control justifies the results of current research as to why IWE did not moderate the relationship between psychopathy and SE, referring to theory of planned behavior which assumed that the psychopaths lacked self-control.

\section{Managerial Implications}

Researchers in the current study argued that dark triads i.e., negative personality traits of an individual could lead to supervisor expediency. Supervisor expediency can be problematic for organization. This study would help practitioners to understand that an individual with dark triad would exhibit morally questionable behavior to negatively affect the organization. Bower and Gilson (2003) highlighted WorldCom as an example where hiding small losses through accounts manipulation led to big losses and brought bad image for the organization. Moreover, research results prove that dark triad significantly affects leader expedient behavior; a supervisor may justify his / her expedient behavior with the thought that it is common and minor. Recruiters need to keep a close eye on the fact that an individual they are hiring must not be scoring high on such traits. Leadership positions are of critical importance in an organization because leaders are considered organization agents and their behavior is attributed to organization practices, technically termed as anthropomorphization. If supervisor at workplace exhibits scheming behavior it would be attributed to the organization and yield negative reputation. In addition, a trickle-down approach may trigger because supervisor involved in unethical practices can prove to be a bad influence on followers. Precisely, the present research is helpful in analyzing what elicits detrimental behavior like expediency. 
Three determinants of SE are identified and empirically investigated. It is also emphasized that IWE are significant mitigating factor between the relationship of dark triad and SE. Organizing workshops to impart high moral values and acknowledge ethical practices is of significant importance at workplace.

\section{CONCLUSION AND FUTURE RESEARCH DIRECTIONS}

Current research incorporated only one moderator i.e., IWE which is one of the limitation of this research. There can be other potential moderators as for example religiosity, empirically it can be investigated that if adoption of IWE could reduce supervisor expediency, whether the religiosity could also weaken the positive relationship between DT and supervisor expediency. In addition, outcomes of supervisor expediency is probable area for research. Future researchers can also investigate contextual antecedents of supervisor expediency, for instance organization culture and climate.

To sum up, dark triad leads to supervisor expediency. Further, IWE is a potential moderator. The current study, in addition to contributing to the relevant literature, provides an insight to practitioners that hiring employee with high score in dark triads could be detrimental for the organization. By strengthening ethical beliefs around Islamic principles could minimize the harmful effects.

\section{REFERENCES}

Ashforth, B. (1994). Petty tyranny in organizations. Human Relations, 47(7), 755-778. doi: doi: https://doi.org/10.1177/001872679404700701

Ajzen, I. (1985). From intentions to actions: A theory of planned behavior. Heidelberg, Germany: Springer.

Aiken, L. S., West, S. G., \& Reno, R. R. (1991). Multiple regression: Testing and interpreting interactions. New York, NY: Sage.

Ali, A. (1992). The Islamic work ethic in Arabia. The Journal of Psychology, 126(5), 507-519. doi:https://doi.org/10.1080/00223980.1992.10543384

Ali, A. (2005). Islamic perspective on management and organization. Cheltenham, UK: Edward Elgar.

Ali, A., \& Al-Owaihan, A. (2008). Islamic work ethic: A critical review. Cross Cultural Management: An International Journal, 15(1), 5-19. doi: https://doi.org/10.1108/13527600810848791

Ali, R. M., \& Wajidi, F. A. (2013). Factors influencing job satisfaction in public healthcare sector of Pakistan. Global Journal of Management and Business Research, 13(8), 61-66.

Allport, G. W. (1937). Personality: A psychological interpretation. New York, NY: H. Holt and. Company.

Allport, G. W. (1961). Pattern and growth in personality. New York, NY: Holt, Rinehart and Winston.

Andreassen, C. S., Ursin, H., Eriksen, H. R., \& Pallesen, S. (2012). The relationship of narcissism with workaholism, work engagement, and professional position. Social 
Behavior and Personality: An International Journal, 40(6), 881-890.

doi: https://doi.org/10.2224/sbp.2012.40.6.881

Babiak, P., \& Hare, R. D. (2006). Snakes in suits: When psychopaths go to work. New York, NY: HarperCollins.

Beekun, R. I., \& Badawi, J. A. (2005). Balancing ethical responsibility among multiple organizational stakeholders: The Islamic perspective. Journal of Business Ethics, 60(2), 131-145. doi: https://doi.org/10.1007/s10551-004-8204-5

Bogart, L. M., Benotsch, E. G., \& Pavlovic, J. D. P. (2004). Feeling superior but threatened: The relation of narcissism to social comparison. Basic and Applied Social Psychology, 26(1), 35-44. doi: https://doi.org/10.1207/s15324834basp2601_4

Bower, J., \& Gilson, S. (2003). The social cost of fraud and bankruptcy. Harvard Business Review, 81(12), 20-23.

Christie, R., \& Geis, F. L. (1970). Machiavellianism. New York, NY: Academic Press.

Cleckley, H. (1976). The mask of sanity: An attempt to clarify some issues about the so-called psychopathic personality. St. Louis, MO: Mosby.

Dahling, J. J., Whitaker, B. G., \& Levy, P. E. (2009). The development and validation of a new Machiavellianism scale. Journal of Management, 35, 219-257. doi: https://doi.org/10.1177/0149206308318618

Dawson, J. F. (2014). Moderation in management research: What, why, when, and how. Journal of Business and Psychology, 29(1), 1-19. doi: https://doi.org/10.1007/s10869013-9308-7

De Hoogh, A. H., \& Den Hartog, D. N. (2008). Ethical and despotic leadership, relationships with leader's social responsibility, top management team effectiveness and subordinates' optimism: A multi-method study. The Leadership Quarterly, 19(3), 297-311. doi: doi: https://doi.org/10.1016/j.leaqua.2008.03.002

DePaulo, B. (2010). The psychology of Dexter. Dallas, TX: BenBella Books.

Djeriouat, H., \& Tremoliere, B. (2014). The dark triad of personality and utilitarian moral judgment: The mediating role of honesty/humility and harm/care. Personality and Individual Differences, 67, 11-16. doi: https://doi.org/10.1016/j.paid.2013.12.026

Duffy, M. K., Ganster, D. C., \& Pagon, M. (2002). Social undermining in the workplace. Academy of Management Journal, 45(2), 331-351. doi: https://doi.org/10.5465/3069350

Einarsen, S., Aasland, M. S., \& Skogstad, A. (2007). Destructive leadership behavior: A definition and conceptual model. The Leadership Quarterly, 18(3), 207-216. doi: doi: https://doi.org/10.1016/j.leaqua.2007.03.002

Eysenck, H. J. (1967). The biological basis of personality (Vol. 689). Illinois, IL: Charles C Thomas.

Eysenck, H. J. (Ed.). (2012). A model for personality. Berlin, Germany: Springer Science $\&$ Business Media.

Fishbein, M., \& Ajzen, I. (1975). Belief, attitude, intention and behavior: An introduction to theory and research, Reading, MA: Addison Wisley.

Fishbein, M., \& Ajzen, I. (1980). Predicting and understanding consumer behavior: Attitudebehavior correspondence. In I. Ajzen, \& M. Fishbein (Eds.), Understanding attitudes and predicting social behavior (pp. 148-172). Englewood-Cliffs, NJ: Prentice-Hall. 
Forsyth, D. R., Banks, G. C., \& McDaniel, M. A. (2012). A meta-analysis of the Dark Triad and work behavior: A social exchange perspective. Journal of Applied Psychology, 97(3), 557-579. doi: doi: https://doi.org/10.1037/a0025679

Greenbaum, R. (2009). An examination of an antecedent and consequences of supervisor morally questionable expediency (Ph.D. Dissertation). University of Central Florida, Orlando, FL.

Greenbaum, R. L. (2007). Understanding and measuring unethical management. In M. Hargis, \& C. Resick (Chairs), Current research on ethical perceptions: Person, context, and interactive perspectives. Paper presented at the Academy of Management Meeting, Philadelphia, PA.

Greenbaum, R. L., \& Folger, R. (2008). Effects of leader bottom-line mentality and rule breaking on subordinate outcomes. In M. Mitchell (Chair), Antecedents and consequences of unethical leadership. Paper presented at the Annual Conference of the Society for Industrial $\mathcal{E}$ Organizational Psychology, San Francisco, CA.

Greenbaum, R. L., Mawritz, M. B., Bonner, J. M., Webster, B. D., \& Kim, J. (2018). Supervisor expediency to employee expediency: The moderating role of leader-member exchange and the mediating role of employee unethical tolerance. Journal of Organizational Behavior, 39(4), 525-541. doi: https://doi.org/10.1002/job.2258

Hare, R. D., \& Thorvaldson, S. A. (1970). Psychopathy and response to electrical stimulation. Journal of Abnormal Psychology, 76(3), 370-374. doi: https://doi.org/10.1037/h0030276

Hare, R. D., \& Neumann, C. S. (2008). Psychopathy as a clinical and empirical construct. Annual Review of Clinical Psychology, 4, 217-246.

doi: https://doi.org/10.1146/annurev.clinpsy.3.022806.091452

Hu, L. T., \& Bentler, P. M. (1999). Cutoff criteria for fit indexes in covariance structure analysis: Conventional criteria versus new alternatives. Structural Equation Modeling: A Multidisciplinary Journal, 6(1), 1-55. doi: https://doi.org/10.1080/10705519909540118

Jonason, P. K., Slomski, S., \& Partyka, J. (2012). The dark triad at work: How toxic employees get their way. Personality and Individual Differences, 52(3), 449-453. doi:https://doi.org/10.1016/j.paid.2011.11.008

Jones, D. N., \& Paulhus, D. L. (2014). Introducing the short dark triad (SD3) a brief measure of dark personality traits. Assessment, 21(1), 28-41. doi: https://doi.org/10.1177/1073191113514105

Khan, K., Abbas, M., Gul, A., \& Raja, U. (2015). Organizational justice and job outcomes: Moderating role of Islamic work ethic. Journal of Business Ethics, 126(2), 235-246. doi: doi:https://doi.org/10.1007/s10551-013-1937-2

Kish-Gephart, J. J., Harrison, D. A., \& Trevino, L. K. (2010). Bad apples, bad cases, and bad barrels: Meta-analytic evidence about sources of unethical decisions at work. Journal of Applied Psychology, 95(1), 1-31. doi: https://doi.org/10.1037/a0017103

Krasikova, D. V., Green, S. G., \& LeBreton, J. M. (2013). Destructive leadership: A theoretical review, integration, and future research agenda. Journal of Management, 39(5), 1308-1338. doi: doi: https://doi.org/10.1177/0149206312471388 
LeBreton, J. M., Binning, J. F., \& Adorno, A. J. (2006). Subclinical psychopaths. In J. C. Thomas, D. L. Segal, \& M. Hersen (Eds.), Comprehensive handbook of personality and psychopathology (Vol. 1). Personality and everyday functioning. Hoboken, NJ: John Wiley \& Sons Inc.

Morf, C. C., \& Rhodewalt, F. (2001). Unraveling the paradoxes of narcissism: A dynamic self-regulatory processing model. Psychological Inquiry, 12(4), 177-19. doi: https://doi.org/10.1207/S15327965PLI1204_1

Murtaza, G., Abbas, M., Raja, U., Roques, O., Khalid, A., \& Mushtaq, R. (2016). Impact of Islamic work ethics on organizational citizenship behaviors and knowledge-sharing behaviors. Journal of Business Ethics, 133(2), 325-333. doi: https://doi.org/10.1007/s10551014-2396-0

Paulhus, D. L., \& Williams, K. M. (2002). The dark triad of personality: Narcissism, Machiavellianism, and psychopathy. Journal of Research in Personality, 36(6), 556-563. doi: doi: https://doi.org/10.1016/S0092-6566(02)00505-6 Palmer, J. C., Komarraju, M., Carter, M. Z., \& Karau, S. J. (2017). Angel on one shoulder: Can perceived organizational support moderate the relationship between the Dark Triad traits and counterproductive work behavior? Personality and Individual Differences, 110, 31-37. doi: https://doi.org/10.1016/j.paid.2017.01.018

PHSP. (2018). Punjab health sector plan 2018; Building a Healthier Punjab. International Growth Centre, Planning \& Development Department, Government of Punjab, Lahore, Pakistan.

Podsakoff, P. M., MacKenzie, S. B., Lee, J. Y., \& Podsakoff, N. P. (2003). Common method biases in behavioral research: A critical review of the literature and recommended remedies. Journal of Applied Psychology, 88(5), 879-903. https://doi.org/10.1037/00219010.88.5.879

Rice, G. (1999). Islamic ethics and the implications for business. Journal of Business Ethics, 18(4), 35-345. doi: https://doi.org/10.1023/A:1005711414306

Robbins, S. P., \& Judge, T. A. (2017). Organizational behavior. London, UK: Pearson Publications.

Syed, J., \& Ali, A. J. (2010). Principles of employees' relations in Islam: A normative view. Employees Relations, 32(5), 454-469. doi: https://doi.org/10.1108/01425451011061630

Tepper, B. J. (2000). Consequences of abusive supervision. Academy of Management Journal, 43(2), 178-190.

doi: doi: https://doi.org/10.5465/1556375

Vohs, K. D., Baumeister, R. F., \& Ciarocco, N. (2005). Self-regulation and self-presentation: Regulatory resource depletion impairs impression management and effortful self-presentation depletes regulatory resources. Journal of Personality and Social Psychology, 8(4), 632657. doi: https://doi.org/10.1037/0022-3514.88.4.632

Vredenburgh, D., \& Shea-VanFossen, R. (2009). Human nature, organizational politics, and human resource development. Human Resource Development Review, 9(1), 26-47. doi: https://doi.org/10.1177/1534484309343094 
Welsh, D. T., Ordonez, L. D., Snyder, D. G., \& Christian, M. S. (2015). The slippery slope: How small ethical transgressions pave the way for larger future transgressions. Journal of Applied Psychology, 100(1), 114-127. doi: https://doi.org/10.1037/a0036950

Yang, Y., \& Raine, A. (2008). Functional neuroanatomy of psychopathy. Psychiatry, 7(3), 133-136. doi: https://doi.org/10.1016/j.mppsy.2008.01.001

Yousef, D. A. (2000). Organizational commitment as a mediator of the relationship between Islamic work ethic and attitudes toward organizational change. Human Relations, 53(4), 513-537. doi: doi: https://doi.org/10.1177/0018726700534003

Yousef, D. A. (2001). Islamic work ethic-A moderator between organizational commitment and job satisfaction in a crosscultural context. Personnel Review, 30(2), 152-169. doi: https://doi.org/10.1108/00483480110380325 